\title{
Qanat water supply systems: a revisit of sustainability perspectives
}

\author{
Fuzhan Nasiri ${ }^{* *}$ and Mohammad Saleh Mafakheri
}

\begin{abstract}
As declared by UNESCO, Qanats are considered as a great human heritage. For many centuries, they presented a rational way of groundwater management in arid rural areas. This paper aims at revisiting this ancient water supply system reviewing its structure and characteristics including construction and operational issues. On that basis, we highlight some key sustainability perspectives related to this ancient water supply practice. We advocate that this ancient technology should not only be protected as a great human heritage but also be reconsidered as a sustainable way of groundwater management in arid/semi-arid regions.
\end{abstract}

Keywords: Qanat, Rural water supply, Groundwater exploitation, Sustainability

\section{Background}

Iran is known as the birth place of Qanat. With an average annual rainfall of $250 \mathrm{~mm}$, it is comprised of vast regions with less than $100 \mathrm{~mm}$ annual rainfall, in the east and center, and small areas in the west and north with up to $1,400 \mathrm{~mm}$ annual rainfall ( Motiee et al. 2006). In such circumstances, an efficient use of subsurface water resources became vital. In this sense, around $800 \mathrm{BC}$, Persians mastered a groundwater exploitation technology (Goblot 1979; Behnia 1988), in form of man-made underground water channels titled Kanehat (now called Kariz or Qanat). This technology was then spread to other Middle Eastern countries, China, India, Japan, North Africa, Spain and from there to Latin America (Abdin 2006; ICQHS 2015).

Qanat captures water seeped into the ground and brings it back to the land surface through a slightly sloped underground tunnel. Qanat technology became the main supplier of water in central Iran, in particular rural areas, for hundreds of years. Such consistency in utilization stems from the fact that Qanats, once built, can provide a steady supply of quality water for many years from groundwater resources far from the villages, with almost

\footnotetext{
*Correspondence: fuzhan.nasiri@concordia.ca

1 Department of Building, Civil, and Environmental Engineering,

Concordia University, Montreal, QC, Canada

Full list of author information is available at the end of the article
}

no operational cost as it uses the force of gravity to create a steady flow (Abdin 2006).

The feasibility of constructing a Qanat system, that could sufficiently supply water during an extended service life, depends on several climatic, geographical and community characteristics. Historically, Qanats were built in areas with low yielding aquifers but in proximity to mountains and hills with high potentials for groundwater resources. Also, Qanats provide a steady flow of water at a low rate and thus are ideal for dispersed rural communities with low population density and low volatility of water demand during the year (Motiee et al. 2006).

Mass migration to cities, availability of high yielding water extraction technologies, and lack of funding to maintain the existing Qanats have resulted in the decline of the share of Qanats in supply of water to rural communities in many Middle-Eastern countries. The climatic change and its impact on regional water resources have also led to decline of water tables (Yin 2003). This resulted in overexploitation of groundwater resources due to excessive issuance of permits for deep wells and caused many Qanats to dry up. As such, the community distribution of water rights that has been provided and protected by Qanats over many centuries is now being replaced by demands, from individual farmers, for deep well permits. This has led to growing inefficiencies in irrigation water uses in a region affected by severe droughts and water scarcity.

\section{Springer}


In this sense, after a brief review of Qanat structure, we will review and emphasize the advantages of Qanats in sustainable provision of quality water in arid/semi-arid regions. The aim of this review is to demonstrate that this ancient system of water supply should not only be protected as a great human heritage but also be reconsidered as part of a sustainable groundwater management agenda in arid/semi-arid rural areas.

\section{Qanat system}

Description of a Qanat and the technologies used to build such a system has been well documented since early times. The Qanat building process has changed very little since that time. Qanats have been constructed by the hand labor of skilled workers, called Muqannis, who have mastered a great understanding of geology and engineering. A Qanat system, as depicted by Fig. 1, consists of the following components (Beaumont 1971; Abdin 2006; Moteei et al. 2006; Boustani 2008; Farzadmehr and Samani 2009; WH 2015):

\section{Mother well}

This is the initial step in building a Qanat. A mother well (with a width of approximately $0.8-1.0 \mathrm{~m}$ ) is dug deep into the water table. As Qanats lead water by the force of gravity, the mother well is usually constructed on alluvial depositions at the bed of mountains and hills. This phenomenon has the advantage of reaching the water at a place and depth that is usually protected from outside contamination. To reach the water table, and locate the place of the mother well, the Qanat builders had to go through a trial an error process by digging a few boreholes. If one of these trial wells could reach the water at a height that provides an acceptable slope for water flow toward the Qanat outlet it is selected as the mother well. The deepest mother well among Qanats, more than $300 \mathrm{~m}$, belongs to the 2,700-year old Gonabad Qanat in Khorasan Razavi province in Iran (Boustani 2008).

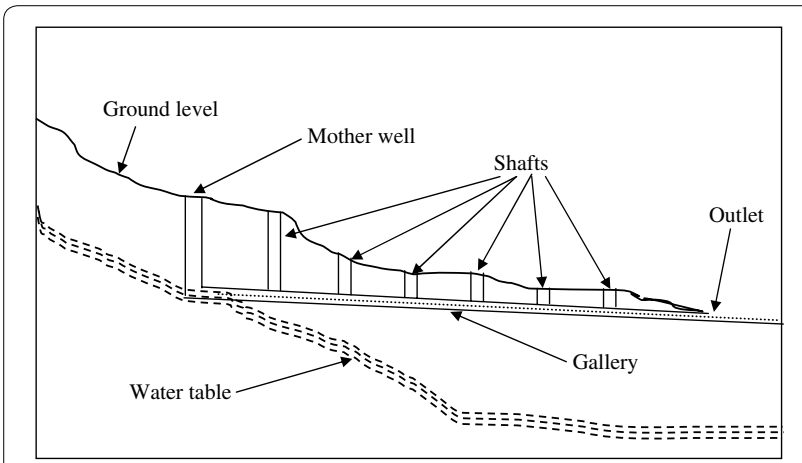

Fig. 1 Structure of a Qanat system.

\section{Outlet}

It is the place that water is emerged to the surface. There are often several candidate positions for the exit point of water. The final location is determined with respect to a number of factors such as the proximity to the points of water consumption (villages, farm lands, etc.) and the slope it makes when connected to the mother well.

\section{Gallery}

Once the mother well and the outlet are located, the Muqannis start to build the gallery, which is a slightly sloped tunnel. The job is started from the outlet toward the mother well. The choice of the slope is a trade off between erosion and sedimentation. Highly sloped tunnels are subject to more erosion as water flows at a higher speed. On the other hand, less sloped galleries need frequent maintenance due to the problem of sedimentation. As seen in most of the Qanats, the slope is around 0.5 percent. The cross-section of the gallery is elliptical with a height of $1.2-2.0$ and width of $0.8-1.0 \mathrm{~m}$. In some advanced Qanats, the bed of the tunnel is sealed by a hard material such as mortar. Also, in loose soils, to avoid roof and wall collapse, baked clay rings are employed. On the basis of the distance between the outlet and the mother well, the length of the gallery could vary from few hundred meters to several kilometers. The longest gallery among the Qanats in Iran, i.e. about $120 \mathrm{~km}$, belongs to Zarach Qanat in Yazd province (Molle et al. 2004).

\section{Shafts}

These are a series of vertical wells built along the gallery between the destination point (water outlet) and the mother well to facilitate the removal of soil and to provide ventilation and access for Muqannis while they are building the gallery. The shafts are built with a $20-50 \mathrm{~m}$ distance from each other and their depth increases toward the mother well. These wells are protected even after the gallery is fully built, as they provide access to Qanat for cleaning and maintenance purposes.

\section{Challenges and issues}

As Table 1 shows, despite the efforts to maintain and refurbish some Qanats with heritage values, the share of Qanats in water supply is decreasing in Iran (Boustani 2008; Farzadmehr and Nazari Samani 2009). From the total volume of water discharge coming from various sources (approximately 69.5 billion $\mathrm{m}^{3}$ ), some $11 \%$ comes from Qanats (Motiee et al. 2006). There are several factors, socio-economic and technical, that contribute to this decline (Motiee et al. 2006). The main socio-economical aspect is the increasing migration of population from rural areas to cities, and consequently, reducing the share of agricultural sector (as the main traditional force 
Table 1 Status of Qanats in Iran

\begin{tabular}{lll}
\hline Years & $\begin{array}{l}\text { Number of } \\
\text { active Qanats }\end{array}$ & $\begin{array}{l}\text { Annual } \\
\text { discharge }^{\text {a }}\end{array}$ \\
\hline $1950 \mathrm{~s}$ & $\approx 21,000$ & 18.1 \\
$1970 \mathrm{~s}$ & $\approx 18,400$ & 7.5 \\
2008 & $\approx 22,000$ & 7.7 \\
\hline
\end{tabular}

a Billion cubic meters (BCM).

behind Qanat development) in economy. From a technical perspective, we may point to two main issues. First, the dewatering of Qanats due to decline of water tables resulted from the extended use of deep wells that pump groundwater faster than its natural replenishment rate. In addition, building a Qanat, using traditional techniques, is very time-consuming, and thus, it is now less preferred to faster alternatives such as deep-wells or inter-basin transmission pipes.

There are a number of issues related to construction and utilization of Qanats which influence their performance, efficiency, and service life:

\section{Water quantity and availability}

The water table selected to feed a Qanat should have a water level adequate and in balance with the demand from the points of consumption. If not, the Qanat would not provide a permanent supply of water and will be dried soon. This would waste the time and resources used for Qanat construction. In fall and winter, with a lower water demand, the Qanat opening in the gallery should be adjusted to save water for high demand seasons. Also, during the nights, excess water could be led to a pond built right after the outlet to be stored for day-time usage.

\section{Water table recharge}

If the natural replenishment process of the aquifer feeding a Qanat is limited, artificial water table recharge tools (such as underground dams, artificial pools, etc.) should be incorporated. For instance, the water table associated with the Jandaq Qanat in Iran is supported by an underground dam (with length of $25 \mathrm{~m}$, width of $1.5 \mathrm{~m}$ and depth of $7 \mathrm{~m}$ ) to sustain the water flow (Abdin 2006).

\section{Water quality}

The slope, roof and wall structure of a Qanat should be designed such that to minimize the erosion. This not only prevents the collapse of the Qanat but also reduces the solid content of the water, which is extremely important if the water is used for drinking purposes. Also, to prevent the risk of contamination (ex. Coliform), knowledge of the proximate sewage systems and other potential sources of water pollution is critical while digging a Qanat.

\section{Maintenance and revitalization}

Periodic maintenance and cleaning of the Qanat is required as sediments might be accumulated in the tunnel of the Qanat after years of water flow.

\section{Water rights and community support}

Water from Qanat could be used for both irrigation and drinking. Thus, a fair water allocation system should be in place to address the needs and preferences of the water users, who are in most case the providers of the financial support for construction and maintenance of Qanats.

\section{Sustainability perspectives}

Over the centuries, Qanats have served as the main supplier of fresh water in arid regions of Iran. They provided the opportunity for people to live in extremely dry zones (even in deserts), and thus helped harmonize the population distribution across the country. Also, farming in saline and alkaline lands became possible using the water supplied through Qanats. In countries with active Qanat systems, socio-economic changes along with some technical drawbacks associated with Qanats (i.e. long construction time, lower rate of water withdrawal, etc.) have significantly increased the use of motor-equipped deep water wells since 1950s. In this sense, comparing a Qanat system with a typical deep well, through their service life, may reveal and highlight the benefits of employing this ancient water supply system in arid areas (Beaumont 1971; Haeri 2003; Alizadeh 2008; Boustani 2008; Farzadmehr and Nazari Samani 2009; WH 2015):

\section{Energy efficiency}

Qanat uses the force of gravity to surface up water. Thus, there is virtually no need to electric power, diesel, pump spare-parts or oil products for lubrication leading to cost recovery and significant energy savings. When compared with diesel motor-equipped deep wells, Qanats also contribute in reduction of green houses gases emissions. Table 2 reflects the potential energy savings of a Qanat by illustrating the energy consumption of electric and diesel deep-well water pumps (Alizadeh 2008).

\section{Life cycle cost}

In spite of being a labor-intensive structure to build, Qanat still poses an efficient choice when compared with deep-wells that have shorter life span (around 20 years) and require frequent replacement and maintenance. A life-cycle comparison of water withdrawal costs for typical Qanats and deep wells is provided in Table 2 (Haeri 2003). A typical Qanat may take years to be built, while a deep well could be dug in few months (Beaumont 1971). We do not present actual data on construction cost and time of Qanat systems due to lack of documentation 
Table 2 Comparison of typical Qanats and deep wells in Iran

\begin{tabular}{|c|c|c|c|c|}
\hline \multirow[t]{2}{*}{ Technology } & \multirow[t]{2}{*}{ Power need $^{\mathrm{a}}$} & \multicolumn{3}{|c|}{ Water withdrawal cost ${ }^{b}$} \\
\hline & & Interest rate $=10 \%$ & Interest rate $=15 \%$ & Interest rate $=20 \%$ \\
\hline Qanat & - & 41.2 & 56.3 & 71.5 \\
\hline Diesel deep well & 4.24 & 89.6 & 103.7 & 118.9 \\
\hline Electric deep well & 2.60 & 67.5 & 88.8 & 111.4 \\
\hline
\end{tabular}

a Horse power ( $\mathrm{Hp}$ ) for extracting 1 liter of water per second.

b 1,000 Rials per 1 cubic meter of water.

and the extent of variation in Qanat systems in terms of length, depth of mother well, and the size of gallery. However, it should be mentioned that the cost and time could be remarkably reduced, compared to traditional practices, with the use of modern digging tools and utilization of geographical information systems and remote sensing technologies to optimally locate Qanat's mother well (Abdin 2006).

\section{Water conservation}

The rate of water flow in Qanat directly depends on the groundwater natural flow preventing over exploitation of the tapped aquifer. Thus, conservation of the aquifer is another advantage of Qanats. In addition, evaporation losses are small as the sealed water transferring channel of Qanat is placed underground, which also reduces water loss from seepage. In areas with low yielding aquifer, where digging deep wells is not a feasible choice, Qanat could well serve the irrigation needs. A hybrid well could also be utilized in such circumstances, which is a Qanat-like gallery attached to a deep well to increase the well yield (Helweg 1973). As such Qanat is a sustainable water supply system that could indefinitely provide water by preserving subsurface water tables (Motiee et al. 2006).

\section{Salinity control}

Qanats transfer freshwater from the mountain plateau to the lower lying plains that have a saltier soil. Thus, the salinity of the soil is kept under control which helps to prevent desertification (Haeri 2003).

\section{Community development}

From a community development point of view, construction and utilization of Qanats could well engage the local population, foster participatory decision making, and provide employment opportunities. It also empowers rural communities to assume responsibility for management and distribution of their water resources (Motiee et al. 2006).

In summary, Fig. 2 presents the tradeoffs between using Qanat systems and deep wells via a casual loop diagram. There are reinforcing tradeoffs/relationships captured by '+' signs, where a change in one element triggers change, in the same direction, in another element. There are also balancing tradeoffs/relationships represented by '-' signs, where a change in one element triggers change, in the opposite direction, in another element. The potential of deep wells in overexploitation of groundwater aquifers serves as the main motivation to sustain a share of water supply from Qanats (represented by a reinforcing/

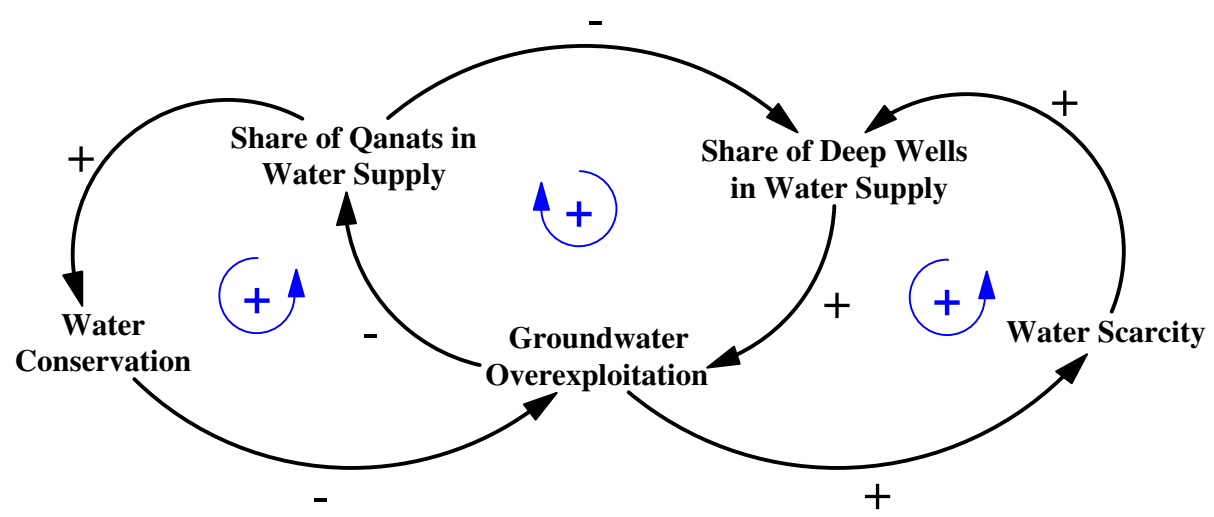

Fig. 2 A systematic representation of tradeoffs between use of Qanats and deep wells for irrigation in arid/semi-arid regions. 
positive causal loop of relationships at the center of Fig. 2). However, the main barrier to maintaining this share would be the increasing water scarcity due to inefficient farming or irrigation practices (represented by a reinforcing/positive causal loop of relationships on the left side of Fig. 2), which encourages the farmers to seek access to a higher number of deep wells which in turn results in overexploitation of groundwater resources and drying of the remaining Qanats (represented by a reinforcing/positive causal loop of relationships on the right side of Fig. 2). In this sense availability of Qanats as an alternative means of water supply, contributes to sustainability of rural communities and optimal management of water resources (Zheng et al. 2011) in the Middle-East region that is under the adverse effects of climate change with severe droughts and widespread water shortages.

\section{Conclusions}

Qanats are considered as a great human heritage, contributing to sustainable management of groundwater (Abdin 2006). In addition to certain construction details such as slope and depth, the performance of a Qanat system is highly influenced by community, geographical, and climate attributes. We advocated that Qanat could present itself as an alternative means of water supply for irrigation uses in arid/semi-arid regions where an increase in the number of deep wells could result in permanent depletion of aquifers. In that sense, we reviewed the advantages of Qanat from a sustainability perspective, while considering its technical/operational limitations. The multiplicity and importance of benefits associated with Qanats emphasize the fact that this ancient technology should be reconsidered, in particular, for provision of irrigation water in arid zones. As a future avenue of research, if the traditional know-how of Qanat building is combined with modern tools and technologies, it may further improve the performance of this water supply system in its long and low maintenance service life.

\section{Authors' contributions}

The authors have co-developed the research agenda and analysis. FN have drafted and revised the manuscript. All authors read and approved the final manuscript.

\section{Author details}

${ }^{1}$ Department of Building, Civil, and Environmental Engineering, Concordia University, Montreal, QC, Canada. ${ }^{2}$ Rural Water and Wastewater Company, Sanandaj, Kurdistan, Iran.

\section{Acknowledgements}

The authors are very much thankful to the reviewers of this paper for their review, helpful comments and suggestions.

\section{Compliance with ethical guidelines}

\section{Competing interests}

The authors declare that they have no competing interests.
Received: 22 June 2015 Accepted: 30 July 2015

Published online: 13 August 2015

\section{References}

Abdin S (2006) Qanats a Unique Groundwater management tool in arid regions: the case of bam region in Iran. In: International Symposium on Groundwater Sustainability (ISGWAS), Jan 24-27, Alicante, Spain

Alizadeh A (2008) Agricultural Water management in Iran: issues, challenges, and opportunities. In: Iran-United States Workshop on Water Management, Sacramento, CA, USA, August 18-19

Beaumont P (1971) Qanat Systems in Iran. Bull Int Assoc Sci Hydrol 16:39-50

Behnia A (1988) Qanat, Construction and Maintenance. University Publishing Centre, Ahvaz

Boustani F (2008) Sustainable Water Utilization in Arid Region of Iran by Qanats. Proc World Acad Sci Eng Technol 33:213-216

Farzadmehr J, Nazari Samani AA (2009) A review of Iran's Qanats (type, current situation, advantageous and disadvantageous) as a traditional method for water supply in Arid and semi arid regions. In: The 2nd International Conference on Water, Ecosystems, and Sustainable Development in Arid and Semi-Arid Zones, May 6-11, Tehran, Yazd, Iran

Goblot H (1979) Les qanats, une technique d'acquisition de l'eau. Ecole des hautes Etudes en Sciences Sociales, Paris

Haeri MR (2003) Kariz (Qanat): an eternal friendly system for harvesting groundwater. In: Adaptation Workshop, Cenesta, New Delhi, 12-13th November

Helweg OJ (1973) Increasing well yield with hybrid wells. Ground Water 11:12-17

ICQHS (2015) Introduction and history of Qanats of Iran. In: International Center on Qanats and Historic Hydraulic Structures, Yazd, Iran. http:// www.icqhs.org/. Accessed 5 Jun 2015

Molle F, Mamanpoush A, Miranzadeh M (2004) Robbing Yadullah's water to irrigate Saeid's garden: hydrology and water rights in a village of central Iran, Research Reports: Vol. 80. International Water Management Institute, Colombo, Sri Lanka

Motiee H, Mcbean E, Semsar A, Gharabaghi B, Ghomashchi V (2006) Assessment of the contributions of traditional Qanats in sustainable water resources management. Water Resour Develop 22:575-588

WH (2015) Qanats. http://www.waterhistory.org/histories/qanats/ Accessed 5 June 2015

Yin YY (2003) Methods to link climate impacts and regional sustainability. J Environ Inform 2(1):1-10

Zheng C, Yang W, Yang ZF (2011) Strategies for managing environmental flows based on the spatial distribution of water quality: a case study of Baiyangdian Lake China. J Environ Inform 18(2):84-90

\section{Submit your manuscript to a SpringerOpen ${ }^{\circ}$ journal and benefit from: \\ - Convenient online submission \\ - Rigorous peer review \\ - Immediate publication on acceptance \\ - Open access: articles freely available online \\ - High visibility within the field \\ - Retaining the copyright to your article}

Submit your next manuscript at springeropen.com 